\title{
Management in a neotropical show cave: planning for invertebrates conservation
}

\author{
Thais Giovannini Pellegrini ${ }^{* 1}$ and Rodrigo Lopes Ferreira ${ }^{2}$
}

\begin{abstract}
:
Pellegrini T.G. and Ferreira R.L. 2012. Management in a neotropical show cave: planning for invertebrates conservation. International Journal of Speleology, 41(2), 359-366. Tampa, FL (USA). ISSN 0392-6672. http://dx.doi.org/10.5038/1827-806X.41.2.19

Lapa Nova is a dolomitic cave about $4.5 \mathrm{~km}$ long located in northwestern Minas Gerais state, Brazil. The cave experiences intense tourism, concentrated over a single period of the year, during the Feast of Our Lady of Lapa. In order to evaluate the impacts felt by the invertebrate community from this tourism, a new methodology was proposed. Four types of areas (intense visitation area, outlying visitation areas, moderate visitation areas and no-visitation areas) were sampled for invertebrates. There was one sampling prior and another on the last day of the $128^{\text {th }}$ feast, to evaluate the effects of visitation on cave-dwelling invertebrates. Results show that invertebrate populations residing in more intensely visited areas of the cave undergo changes in distribution following the event. As a consequence of tourism, invertebrates shift to outlying locations from the visited area, which serve as refuges to the communities. Apparently, the fact that there are places inside Lapa Nova inaccessible to tourists reduces the impact suffered by the invertebrate community, as those sites serve as refuges for cave-dwelling organisms during the pilgrimage. A proper management plan was devised for the tourism/religious use of the cave. It consists basically of delimiting marked pathways for tourists, allowing invertebrates to seek shelter at locations outside visited areas and keeping no-visitation areas off-limits to tourism based on the results of the visitation effects on cave-dwelling invertebrates.
\end{abstract}

Keywords: management plan; conservation; displacement; tourism; pathway

Received 12 March 2012; Revised 31 May 2012; Accepted 4 July 2012

\section{INTRODUCTION}

Caves are ecologically important due to several distinct features. In these systems, there is the total absence of light, which exerts intense evolutionary pressure on existing species, serving as a barrier to the colonization of caves by various epigean (surfacedwelling) organisms (Culver \& Pipan, 2008). Another condition imposed on cave-dwelling environments is the environmental parameter range variation, especially temperature, which is lower than that found in the surrounding outside environment (Poulson \& White, 1969; Barr \& Kuehne, 1971).

In addition to peculiar environmental conditions, caves feature a set of unique geological formations, with great scenic beauty, which serve as attractions for tourist use of these systems. Hamilton-Smith (2004) defined tourist caves simply as those that pique the interest of the general public, charging ad-

${ }^{1}$ PPG- Applied Ecology, Department of Biology (DBI), Federal University of Lavras (UFLA), Minas Gerais, CEP: 37200-000, Brazil (thais.g.pellegrini@gmail.com) *Corresponding author

${ }^{2}$ Laboratory of Underground Ecology, Department of Biology (DBI), Federal University of Lavras (UFLA), Minas Gerais, CEP: 37200-000, Brazil (drops@dbi.ufla.br) mission or generating another type of financial return (e.g. sale of souvenirs). Worldwide, tourism in natural caves has been taking place for many years in various caves, many of which receive thousands of visitors every year.

In Brazil, religious motivation can be considered the precursor of cave tourism. These cultural manifestations take place mainly in entrance areas, but in certain cases they can extend to innermost regions of caves. In any given form, these cultural manifestations have unquestionable heritage value. However, they can have different impacts on cave environments, either physical or biological (Pulido-Bosh et al., 1997; Hamilton-Smith, 2004; Lobo et al., 2007; Romero, 2009).

According to Hamilton-Smith (2004), the most severe impacts in tourist caves usually result from inappropriate use, with inadequate infrastructure and facilities. In order to minimize problems inherent to tourism/religious use of a cave, an adequate management plan must be devised for its condition and proposed use.

To that end, attempts should be made to preserve, a priori, organisms under greater risk of extinction. Troglobites, which are organisms restricted to these environments, can often be found in caves. 
These species tend to feature a high degree of endemism and are often restricted to a single cave (Barr \& Holsinger, 1985), making them the focus for conservation. Moreover, the most effective way to ensure the protection of species vulnerable to extinction is by guaranteeing the conservation of the entire ecosystem associated with them (Eberhard, 2001).

In order to evaluate the effects of a unique tourist use (thousands of visitors within three days) on the fauna of a cave, as well as to propose solutions aiming at greater conservation of the communities associated with it, this work aimed to: i) evaluate the changes in the invertebrate community resulting from human visitation to Lapa Nova cave; ii) determine the distribution of troglomorphic organisms throughout the entire cave; iii) determine the distribution of spiders of the genus Loxosceles, which offer risks to visitors; $i v)$ propose guidelines for a fauna management program for this cave, aiming towards its tourism-religious use while minimizing the impacts caused by those activities.

\section{MATERIALS AND METHODS}

\section{Study area}

The present study was carried out at the Lapa Nova dolomitic cave, located in Vazante, northwestern Minas Gerais state, southeastern Brazil. It is the $34^{\text {th }}$ largest cave in the country, and sixth in the state (Auler et al., 2001).

Lapa Nova is of great importance not only for its size and geological attributes, but also because of its urban setting and frequent visitors. The cave, although lacking any structure or management plan for mass tourism, has been visited for at least 128 years by tourists and pilgrims of the Feast of Our Lady of Lapa, serving as a local tourist hub (Auler et al., 2001). The event is one of the largest religious feasts in Brazil, taking place on May $1^{\text {st }}, 2^{\text {nd }}$ and $3^{\text {rd }}$, and featuring a temporary population of up to 50 thousand people (Oliveira Mello, 1977).

\section{Study methodology}

A sampling of invertebrates was carried out throughout the entire cave, including areas forbidden for visitation, except at upper levels, due to the access difficulties and the lack of access by tourists. The collection was done manually, using tweezers, brushes and hand nets, paying special attention to microhabitats such as under trunks and rocks, as well as other organic matter accumulations, as per the methodology proposed by Ferreira (2004). Each species was represented by a number, plotted on a map at the location where it was captured or observed.

The present work features a new methodology to evaluate the effects of visitation on cave-dwelling invertebrates. To that end, a prior inventory was essential to determine areas of greater concentration of organisms, in order to focus sampling areas before and during the visitation period. The new methodology proposal is described next.

Four area classifications were assigned to be inspected in detail, with one prior sampling (April 10, 2009) and another on the last day of the $128^{\text {th }}$ feast (May $3^{\text {rd }}$, 2009). During the whole festival, there was a team in the cave entrance that counted the number of visitors that entered in each part of the cave, considering the number of visitors in each area the classifications were: 1) intense visitation areas; 2) outlying visitation areas; 3) moderate visitation areas; and 4) non-visited areas (access forbidden to tourists).

In each of these areas, rectangles were demarcated on the ground, $45 \mathrm{~m}^{2}(3 \times 15 \mathrm{~m})$ each. This size was randomly defined. However, to choose the areas, we considered locations where a high number of invertebrate individuals were known to exist, therefore, the number of rectangles per area varied. It was important to choose these areas because locations with very low densities would negate the tourism effects. Finally the shape (rectangular) is that more suitable to fit in the narrow passages (especially those restricted to visitor pathways). Thus, three rectangles were laid out in the high-visitation area, two in outlying-visitation areas, one in the moderate-visitation areas, and four in novisitation areas (Fig. 1). The same four persons did the collection at each rectangle; it was done manually, using tweezers, brushes and hand nets. We concentrated the sampling on the cave floor because human impacts are more evident on this substrate, especially by trampling and ground compaction. Furthermore, the cave roof is, on average, very high (more than 10 meters high), which prevented us from examining in such areas detail. The cave walls were inspected until the visible area, revealing only a few specimens. The majority of the invertebrates in the cave were probably on the cave floor (due to the presence of organic debris - which accumulates on the floor).

The turnover of species in each rectangle $(\beta$ diversity) was determined as well. This parameter determines the rate of species turnover in a given system over time. Thus, by comparing the invertebrates

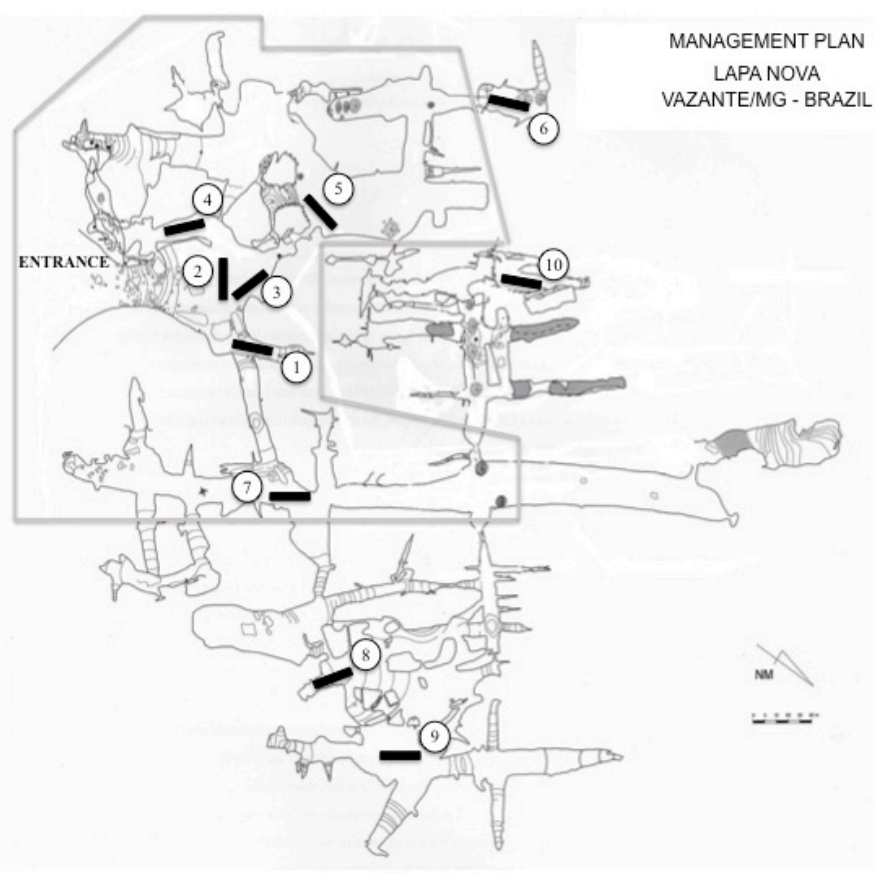

Fig. 1. Map of Lapa Nova detailing all ten sampling rectangles. Rectangles 1,2 and 4 are those in the intense-visitation area; 3 and 5 , are the rectangles in outlying visitation areas; 7 is the rectangle in areas with moderate visitation intensity; and 6 and 8 to 10 are the rectangles placed in non-visited areas. Adapted from Auler et al. (2001). 
observed prior to and during the last day of intense tourism, turnover ( $\beta$ diversity) was determined from data on presence and absence, using Harrison's index (1992) as modified by Whittaker (1960).

Turnover is represented by:

$$
\left.\beta \text { Harrison }=\{[(\mathrm{S} / \mathrm{a})-1] /(\mathrm{N}-1)\}^{*} 100\right)
$$

in which: $\mathrm{S}=$ total richness observed, $\mathrm{a}=$ mean richness per rectangle, and $\mathrm{N}=$ number of samplings (in this case, $\mathrm{N}=2$, represents the collections before and during tourism, for each rectangle). Next, the average turnover was calculated for the rectangles located in areas of high, outlying and no-visitation areas. Those measurements ranged from 0 (no species turnover) to 100 (each season features a unique set of species; that is, the community was completely replaced from one season to the next) (Koleff et al., 2003). It is assumed herein that more "stable" areas from an ecological viewpoint have lower species turnover over time.

Analyses of richness and abundance were carried out for invertebrates in all rectangles. Comparisons between the parameters obtained in each collection period (prior to and during the last day of tourist use) were carried out using Student's t-test.

The mean number of species added or lost after the tourism event was evaluated for all rectangles. The difference in richness in the rectangles was represented by a column graph; the means and graph were obtained using Statistica software. Next, SIMPER (Similarity Percentage) was used to determine the contribution of each species to the average Bray-Curtis dissimilarity between different rectangle groups. This method of analysis determines which species are responsible for any differences that occur.

The similarity in the fauna of high-visitation and no-visitation rectangles was compared using Nonmetric Multidimensional Scaling ( $n-M D S)$ through the Jaccard index. The existence of significant differences between n-MDS groups was evaluated by ANOSIM (Analysis of Similarities). Lastly, SIMPER analysis was used to evaluate which species were responsible for those differences. All above-mentioned analyses were carried out using Past software.

The general inventory of the cave was also used to assess the threat level to visitors from spiders of the genus Loxosceles. To that end, a map was devised featuring the abundance and distribution of those life forms throughout the entire cave. Likewise, a map featuring the distribution of troglomorphic organisms was also elaborated. Using both maps, it was possible to detail the areas with the greatest potential risk for accidents with visitors throughout the cave and determine zones of higher concentration of endangered organisms. Those zones were deemed preferential for prohibition against tourist use.

The management plan was devised from the fauna distribution maps (with special attention to the distribution of Loxosceles spiders and troglomorphic organisms), and also considering the changes observed in the distribution of those populations as the result of intense visitation.

\section{RESULTS}

\section{Characterization of changes in the cave}

The historic use of the cave includes the installation of infrastructure including stairways, guardrails and striped tape that delimit the marked pathway area, although those structures are quite precarious. The $128^{\text {th }}$ feast had a total of 4,244 visitors. Of those, $3,292(77 \%)$ visited only the main room of the cave. Among the different changes caused by anthropic use of the cave was significant compaction of the soil in the tourist route, from intense stepping. Some visitors incorrectly climb on speleothems, which harms the creation of those formations. Others remove cave pearls, believing they have curative powers. There are also several instances of graffiti and trash left by tourists during visits.

With regard to fauna, there are reports of direct stepping on animals by tourists, especially spiders. Furthermore, it was reported that the local government, in an attempt to control the Aedes aegypti population, sprayed mosquito poison on the small pools and travertine dams inside the cave.

\section{Changes observed in invertebrate communities within the rectangles}

The data generated from the calculation of species turnover showed that no-visitation areas are the most stable, as they showed low average turnover - 36 . Conversely, high-visitation areas had a higher species turnover rate -42 . Outlying visitation areas featured the highest average turnover rate (62), with the highest rate of species immigration.

Fig. 2 depicts the average number of species gained or lost after the tourism event, evaluated for all rectangles. Rectangles located in high-visitation locations suffered greater losses of species on average; whereas rectangles located outlying visitation areas showed the highest species gain. For their part, the rectangles situated in locations were visitation is prohibited remained the most stable in number, with only a small gain in species.

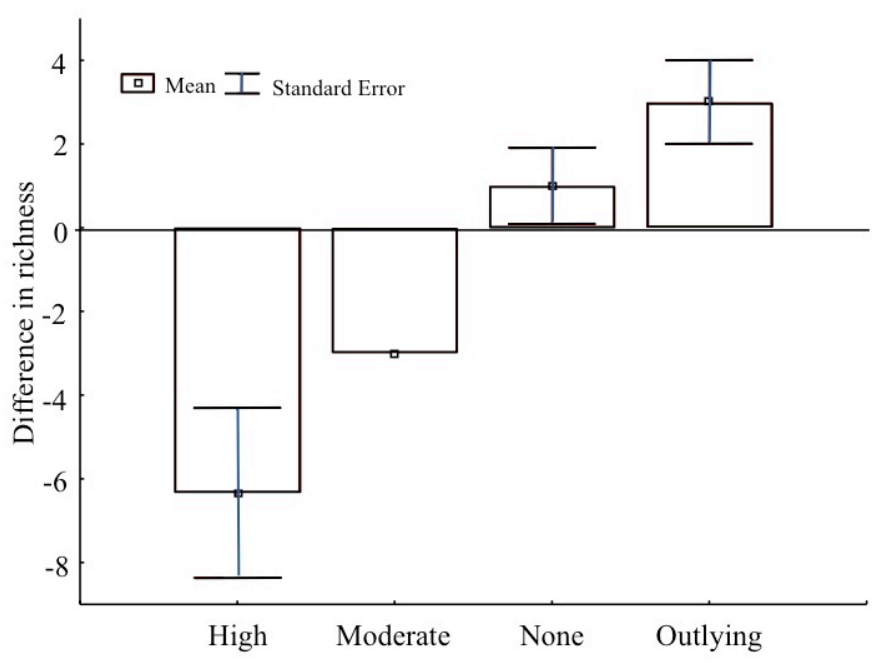

Fig. 2. Mean number of species "gained" or "lost" after the tourism event, evaluated for all rectangles. 


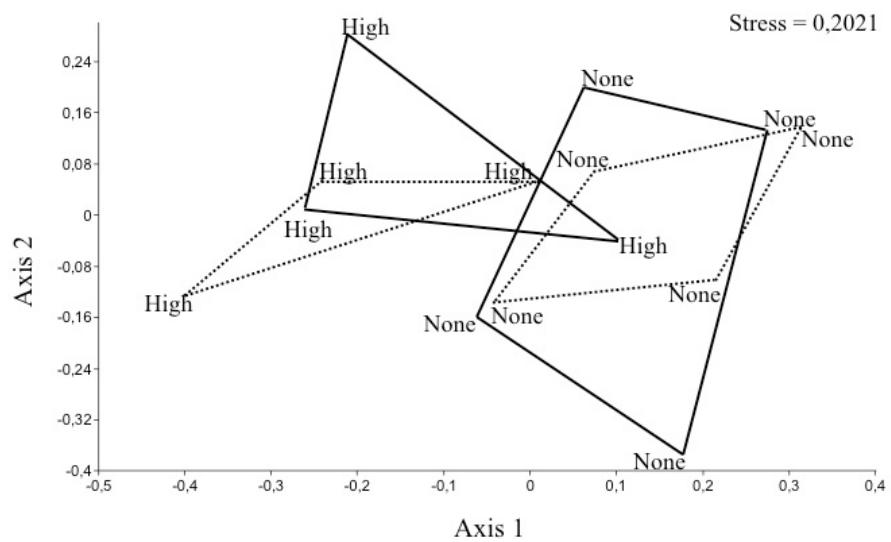

Fig. 3. Multidimensional scaling (n-MDS) of none- and highvisitation rectangles, before (continuous line) and during the last day (dotted line) of the pilgrimage. Jaccard similarity coefficient.

According to SIMPER analysis, in the last day of pilgrimage, many of the species that showed significant abundance declines in the high-visitation rectangles increased their abundance in outlying visitation rectangles. They were: Hebridae sp1 (Hemiptera); Collembola sp1; Cholevidae sp1 (Coleoptera); Staphylinidae sp4 (Coleoptera); Chernetidae sp1 (Pseudoscorpiones); Rhagidiidae sp1 (Trombidiformes) and Tineidae sp2 (Lepidoptera). It should also be mentioned that the first two listed species, combined, represented $34 \%$ of the dissimilarities observed between the two rectangle groups. It was also possible to verify that some of the species that disappeared from the high-visitation rectangles emerged in outlying visitation areas. The species that showed this behavior were: Theridiidae sp10, Carabidae sp1, Cicadellidae sp 1 and Laelapidae sp1 (Table 1).
The rectangles sampled to assess the changes resulting from high-visitation (three rectangles) and from locations with no visitation (four rectangles) contained a total of 59 species. n-MDS analysis (using the Jaccard index - stress equal to 0.2) evidenced a greater difference in fauna composition due to tourism in the high-visitation rectangles. Rectangles situated at low-visitation locations did not show any such evident difference (Fig. 3).

The differences between the groups analyzed by the Jaccard index were almost significant (ANOSIM $\mathrm{p}=0.051)$. Nevertheless, in light of the small sample number, a variation effect could occasionally be alleged for the communities as a function of intense visitation.

According to the SIMPER analysis, the species that most contributed to the differences before and during tourist use in the high-visitation rectangles were: Hebridae sp1 (Heteroptera), responsible for approximately $16.4 \%$ of those differences; followed by Psyllipsocus sp3 and Collembola sp1, with approximately 6.9\% each; Loxosceles variegata (Araneae) with 6.6\%; and Endecous sp (Ensifera) with 6.3\% (Table 2). Those species combined accounted for more than $50 \%$ of the differences in similarity among the sampled rectangles. Moreover, all the above-mentioned species showed a decrease in abundance during the tourism period.

In contrast, the SIMPER analysis performed in the no-visitation rectangles, before and during the pilgrimage, showed that the species responsible for the dissimilarities among these rectangles were: Cholevidae sp1 (Coleoptera), responsible for $11.8 \%$; Loxosceles variegata (Araneae), with 10.9\%; Endecous sp (Ensifera), with 10\%; and Collembola sp1, with

Table 1 SIMPER analysis. Comparison between the abundance of species present in the rectangles with high visitation or outlying to visitation.

\begin{tabular}{|c|c|c|c|c|c|c|}
\hline & & & \multicolumn{2}{|c|}{ High-visitation } & \multicolumn{2}{|c|}{ Outlying-visitation } \\
\hline Taxon & Contribution & Cumulative $\%$ & Abund. Before & Abund. After & Abund. Before & Abund. After \\
\hline Hebridae sp1 & 15.11 & 18.12 & 23.7 & 18.7 & 6 & 47 \\
\hline Collembola sp1 & 13.44 & 34.23 & 13.7 & 5.33 & 20.5 & 48.5 \\
\hline Psyllipsocus sp3 & 6,408 & 41.91 & 9.33 & 6.33 & 8.5 & 1 \\
\hline Loxosceles variegata & 4,261 & 47.02 & 4 & 2.33 & 0.5 & 0 \\
\hline Endecous sp & 3,983 & 51.8 & 4 & 0.333 & 1.5 & 1 \\
\hline Nematoda sp & 3,766 & 56.32 & 0 & 0 & 5.5 & 0 \\
\hline Cholevidae sp & 2,829 & 59.71 & 2.33 & 0.667 & 3 & 7.5 \\
\hline Cydnidae sp3 & 2,422 & 62.61 & 2.33 & 3 & 0 & 8.5 \\
\hline Conicera sp1 & 2,331 & 65.41 & 0 & 0.667 & 0 & 16.5 \\
\hline Formicidae sp4 & 2,315 & 68.18 & 10.3 & 0.667 & 0 & 0 \\
\hline Staphylinidae sp4 & 2.27 & 70.91 & 3.67 & 3 & 3 & 3.5 \\
\hline Theridiidae sp10 & 2,067 & 73.38 & 1 & 0 & 0 & 2 \\
\hline Diptera sp3 & 2,027 & 75.81 & 0 & 0 & 0 & 2.5 \\
\hline Chironomidae sp2 (larva) & 1,643 & 77.78 & 0 & 0 & 2 & 0.5 \\
\hline Trichorhina sp & 1,603 & 79.71 & 1.33 & 1 & 0 & 3 \\
\hline Carabidae sp1 & 1,465 & 81.46 & 1.67 & 0 & 0 & 4 \\
\hline Chernetidae sp1 & 1,376 & 83.11 & 1.67 & 0.333 & 0 & 1 \\
\hline Lumbricidae $\mathrm{sp}$ & 1,193 & 84.54 & 1.67 & 0.333 & 3 & 1 \\
\hline Rhagidiidae $\mathrm{sp}$ & 1,008 & 85.75 & 1.67 & 1 & 0 & 3 \\
\hline
\end{tabular}




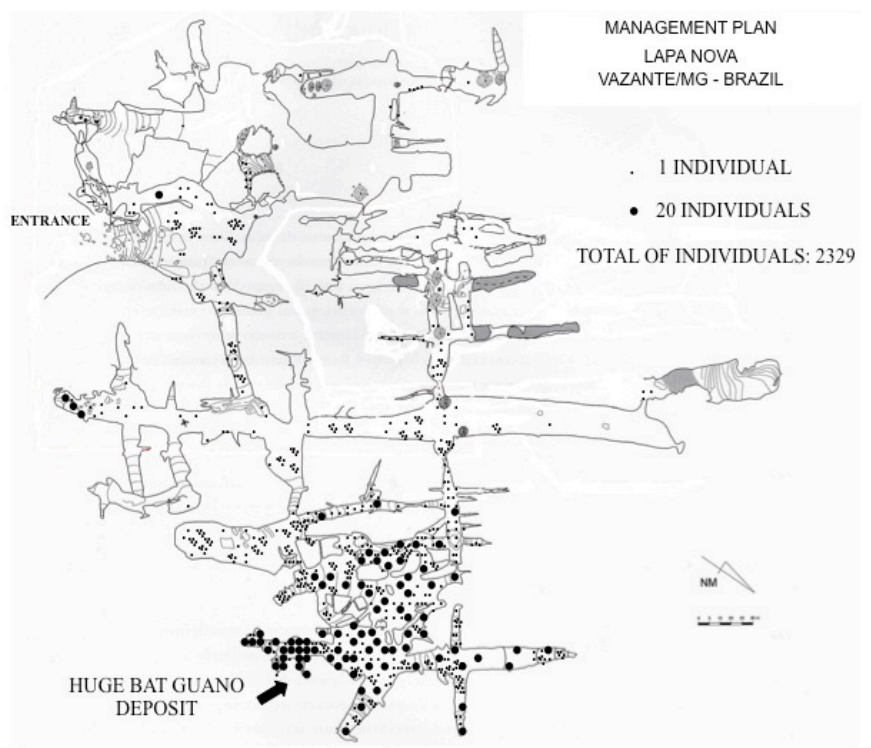

Fig. 4. Distribution of Loxosceles variegata at Lapa Nova, point represents $L$. variegata individuals. Adapted from Auler et al. (2001).

8.8\% (Table3). Those species combined accounted for more than $50 \%$ of the differences in similarity among the sampled rectangles. It was not possible to observe a pattern of increased or reduced abundance for the above-mentioned species.

Observing the distribution map for spiders of the genus Loxosceles, it is clear that those life forms are not uniformly distributed throughout the cave (Fig. 4). There are areas with low density of individuals, whereas others are densely populated. The cave region worthy of highlight is the main room (and adjacent structures) close to a large deposit of guano from omnivorous bats of the genus Phylostomus.

Table 2. SIMPER analysis. Species that most contributed to the dissimilarities shown by high-visitation rectangles sampled before and during the pilgrimage.

\begin{tabular}{|l|l|l|l|l|}
\hline & & & \multicolumn{2}{|c|}{ High-visitation } \\
\hline TAXA & Contribution & Cumulative \% & Antes & Depois \\
\hline Hebridae sp1 & 16.43 & 21.06 & 23.7 & 18.7 \\
\hline Psyllipsocus sp3 & 6,928 & 29.94 & 9.33 & 6.33 \\
\hline Collembola sp1 & 6,882 & 38.76 & 13.7 & 5.33 \\
\hline Loxosceles variegata & 6,604 & 47.23 & 4 & 2.33 \\
\hline Endecous sp & 6,327 & 55.34 & 4 & 0.333 \\
\hline Formicidae sp4 & 4.33 & 60.89 & 10.3 & 0.667 \\
\hline Cydnidae sp3 & 2,698 & 64.35 & 2.33 & 3 \\
\hline Cholevidae sp & 2,569 & 67.64 & 2.33 & 0.667 \\
\hline Staphylinidae sp4 & 2,468 & 70.8 & 3.67 & 3 \\
\hline Chernetidae sp1 & 2,237 & 73.67 & 1.67 & 0.333 \\
\hline Carabidae sp1 & 2,225 & 76.52 & 1.67 & 0 \\
\hline Trichorhina $\mathrm{sp}$ & 2.21 & 79.36 & 1.33 & 1 \\
\hline Acherontides $\mathrm{sp}$ & 1,967 & 81.88 & 2 & 0 \\
\hline Ctenus $\mathrm{sp}$ & 1.57 & 83.89 & 1 & 0 \\
\hline Theridiidae sp10 & 1.57 & 85.9 & 1 & 0 \\
\hline
\end{tabular}

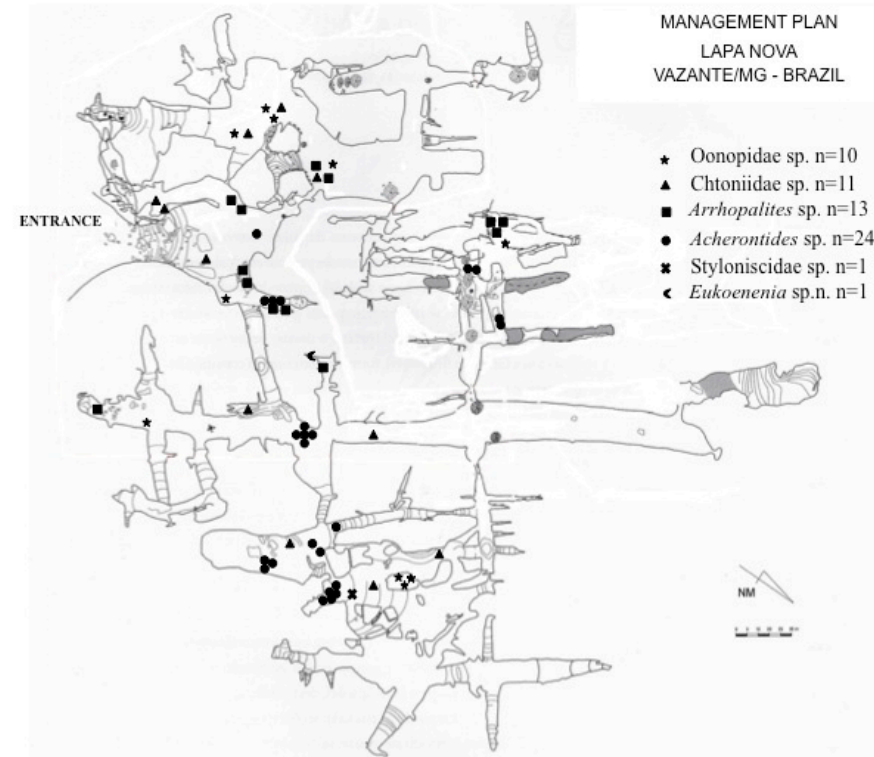

Fig. 5. Map of Lapa Nova detailing the distribution and occurrence of possible troglobite organisms found in the cave. Adapted from Auler et al. (2001).

Six troglomorphic species were found: Arrhopalites sp. (Collembola: Arrhopalitidae), Acherontides sp. (Collembola: Hypogastruridae), Eukoenenia sp.n. (Palpigradi: Eukoeneniidae), Oonopidae sp. (Araneae), Chthoniidae sp. (Pseudoscorpiones) and Styloniscidae sp. (Isopoda). There was no single preferred distribution area for troglomorphic species in the cave. Most of the species (except the Styloniscidae and Eukoenenia sp.n). were well distributed throughout the cave, occurring both in visited areas and those not frequented by tourists (Fig. 5). However, with rare exceptions, these organisms, when in visitation areas, were preferably located in areas peripheral to intense tourist traffic (the main marked pathways).

\section{DISCUSSION}

According to Culver \& Sket (2002), caves with large numbers of visitors and modifications can feature a high diversity of species. This shows that opening a cave to tourism is not incompatible to preserving its biodiversity, as in the cases of certain show caves: Postojna - Planina Cave System (Slovenia), Baget - Sainte Catherine System (France), Shelta Cave (Alabama, USA), Mammoth Cave (Kentucky, USA) and Vjetrenica Cave (Bosnia \& Herzegovina) (Culver \& Sket, 2002).

However, there are two great problems involving the conservation and management of underground systems: defining the criteria to be used, and the techniques to monitor the changes (Gunn et al., 2000). Even if some authors indicate measures to help execute a good management plan (Hamilton-Smith, 2004), this is not always possible. That is the case of the management plan devised for Lapa Nova, as tourism in the cave has taken place for over a century without any prior study.

One peculiar aspect of Lapa Nova is the occurrence of religious tourism over only three days of the year, during the Feast of Our Lady of Lapa. In most tourist caves worldwide, even if annual visitor volumes are greater than Lapa Nova, visitation is better 
Table 3. SIMPER analysis. Species that most contributed to the dissimilarities shown by no-visitation rectangles sampled before and during the pilgrimage.

\begin{tabular}{|l|l|l|l|l|}
\hline & & & \multicolumn{2}{|c|}{ No-visitation } \\
\hline TAXA & Contribution & Cumulative \% & Before & After \\
\hline Cholevidae sp & 11.85 & 15.22 & 20.3 & 7.5 \\
\hline Loxosceles variegata & 10.97 & 29.31 & 12 & 24.3 \\
\hline Endecous $\mathrm{sp}$ & 10.05 & 42.21 & 21.8 & 25.3 \\
\hline Collembola sp1 & 8,885 & 53.62 & 34.3 & 3.25 \\
\hline Staphylinidae sp4 & 5.66 & 60.89 & 7.5 & 6.25 \\
\hline Diptera sp1 & 3,691 & 65.63 & 1 & 8.75 \\
\hline Psyllipsocus $\mathrm{sp} 3$ & 3,518 & 70.15 & 2 & 3.75 \\
\hline Blattodea sp & 3,031 & 74.04 & 7.5 & 5.75 \\
\hline Drosophilidae sp & 2,682 & 77.49 & 4 & 0 \\
\hline Lutzomyia $\mathrm{sp}$ & 2,627 & 80.86 & 4 & 0 \\
\hline Theridiidae $\mathrm{sp} 10$ & 2,351 & 83.88 & 1.75 & 3 \\
\hline Ctenus $\mathrm{sp}$ & 2,224 & 86.73 & 6.25 & 3.5 \\
\hline
\end{tabular}

distributed throughout the year. Some authors defend a daily cutoff in visitor number to avoid permanently affecting the environmental parameters of the cave environment (Cigna, 2005; Romero, 2009). However, the concentration of visitors during the Feast of Our Lady of Lapa makes that practice impossible, hindering any management of Lapa Nova.

Many of the studies available in the literature evaluate the microclimatic changes resulting from tourism, such as temperature, humidity and $\mathrm{CO}_{2}$ (Pulido-Bosch et al., 1997; Baker \& Genty, 1998; Song et al., 2000; Calaforra et al., 2003; Russel \& MacLean, 2007). An assessment of existing management models in show caves in Croatia showed that of the 13 caves under study, nine fit the category of geomorphological protection, and there is no mention of conservation of cave-dwelling fauna in any of the 13 proposed managements (Bocic et al., 2006).

Therefore, little is known of the impact on underground fauna from visitation activities (Gunn et al., 2000). Few studies use biological parameters such as richness, abundance and presence of rare species to delimit tourist use of natural caves (Ferreira et al., 2009). The scarcity of studies considering biological criteria likely results from the experimental difficulty in evaluating the impacts suffered by cave-dwelling fauna, as well as the low densities of many of these populations (Eberhard, 2001).

In Brazil, few works exist on management initiatives including measures to minimize the impacts on the invertebrate fauna. Proposals vary in the methodology for conservation: some simply isolate areas with higher concentrations of troglobite species, as in Maroaga Cave (Presidente Figueiredo - AM) and the Botuverá I and II grottos (Vale do Itajaí, SC) (Sessegolo et al., 2004a; Sessego et al., 2004b). Other studies are more complex and involve creating well-defined marked pathway routes in order to reduce the area affected by excessive stepping by visitors, such as the case of Lapinha Grotto (Lagoa Santa - MG), Santo Antônio Grotto (Itumirim - MG), as well as Aroê
Jarí, Kiogo Brado and Lago Azul grottos (Chapada dos Guimarães - MT) (Ferreira, 2004; Ferreira et al., 2009). Some authors propose the translocation of the invertebrate fauna towards the non-visited areas of the cave using organic incentives, as in the case of Maquiné grotto, (Cordisburgo-MG) (Ferreira, 2004; Ferreira et al., 2009).

The new method developed in this work - using one collection before and another during the tourist use of the cave - allows the evaluation of direct damage to invertebrate fauna as well as changes in the spatial distribution of the community. The fauna moves to locations where the effect of tourism is not very intense, as evidenced by the high species turnover observed at sites with high-visitation and outlying visitation areas. Similar population displacements were observed in Chico Rei Mine, Ouro Preto - MG, which is used for tourism (Bernardi et al., 2010). Contrarily, at Maquiné Grotto, a greater density of fauna was observed in the region of tourist concentration (Ferreira, 2004). The populations migrated to regions with greater availability of feeding resources (leftovers from tourists). The response to tourism at Lapa Nova occurs with the migration of species to outlying regions of tourist traffic sites.

Eberhard (2001) used a different strategy to monitor disturbances to the community from tourism in Ida Bay Karst, southern Tasmania. That author used spiders and crickets as indicators, as they featured a wider distribution and greater abundance compared to other organisms. In the case of Lapa Nova, the responses by Loxosceles variegata and Endecous sp. can represent a good pattern of the disturbances suffered by the community. Both are among the species that most influenced the differences between the rectangles before and during visitation. Moreover, $L$. variegata deserves further attention for its medical relevance; it is crucial to keep the tourist route far from the highest population densities of that creature.

In any case, monitoring the populations of caves with tourist use is worthwhile to establish changes in spatial distribution patterns in the cave. Changes in population sizes and taxonomic composition of cavedwelling fauna should be monitored (Culver \& Sket, 2002).

Finally, the management plan considered two principal aspects, (a) the first argument lies in the protection of the invertebrate community; (b) the other considered the safety of the tourists, considering potentially dangerous animals. The proposal was devised from the responses of cave-dwelling life forms, aiming to protect the entire cave-dwelling habitat and fauna, in order to ensure the maintenance of equilibrium in the community. This measure is essential given the difficulty in precisely identifying the invertebrates found and effectively determining which species are most vulnerable to extinction from adverse disturbances such as unbridled tourism (Eberhard, 2001).

Therefore, in biological terms, the management recommended for Lapa Nova consists basically of blocking tourism in certain areas of the cave and defining a well-delimited marked pathway. Areas offlimits to tourism are those that feature greater concentrations of troglomorphic species and high species diversity, aiming towards the cave dwelling species 


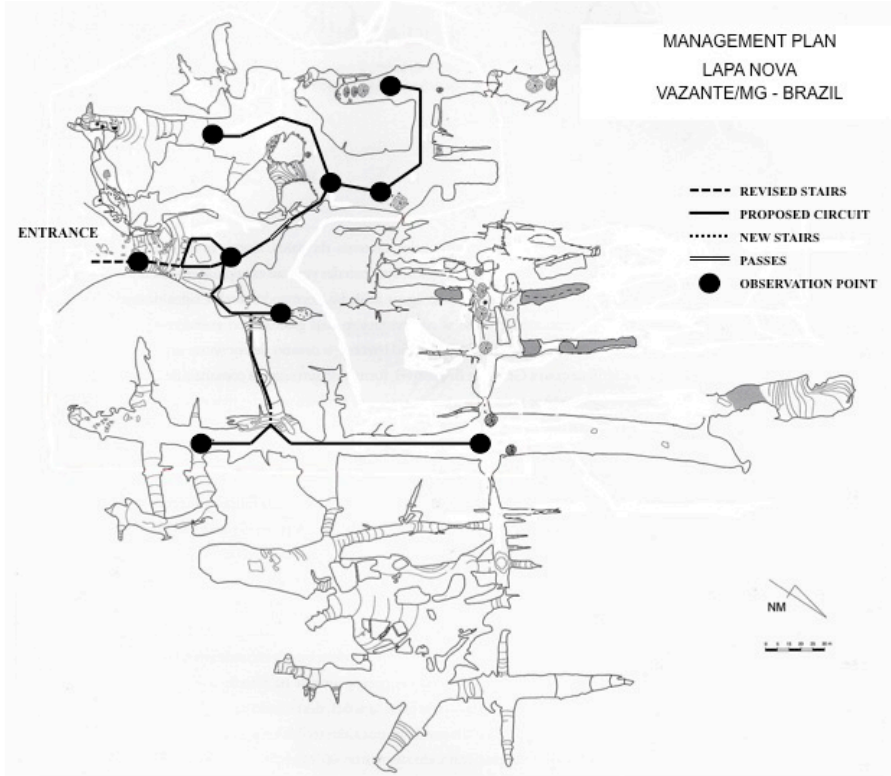

Fig. 6. Marked pathway proposed by the Lapa Nova speleological management plan. Adapted from Auler et al. (2001).

conservation; and also areas presenting large deposits of guano (a potential substrate for the establishment of pathogenic fungi such as Histoplasma capsulatum) (Fig. 4), higher densities of L. variegata, or offer difficult access or risk of accidents, considering the safety of the tourists. Those conclusions were possible only by using the applied methodology of actively searching for organisms, which made it possible to more precisely identify the preferred locations of each species. Regarding the marked pathway, is important to install small footbridges in areas where the floor is very uniform. These footbridges would prevent direct contact with the floor of the cave, so that invertebrate communities would have shelter without being directly affected.

Fig. 6 depicts the final marked pathway proposed in the management plan recommended for Lapa Nova (Carste Consultores Associados, 2009), which considered the overlap of biological issues with physical, geological and paleontological aspects. The result of the proposal included the modification of the current pathway, transferring it to places with no fragile speleothems. Cave protection structures such as ladders and footbridges should be installed for situations when it becomes necessary to access those locations. All marking lines (striped tape) should be removed, as well as their supports (concrete and wooden beams). The delimitation of the marked pathway should be done at ground level, preserving the scenic beauty of the place.

The management plan proposed for Lapa Nova aimed to follow proposals already applied in other Brazilian caves, by delimiting a well-defined pathway for tourists, so as to achieve coherence among the applied criteria. After effectively implementing the management plan, it is essential that the communities be monitored to find out whether the intervention of the management led to the desired responses (Ferreira, 2004). Finally, the biological management plan at Lapa Nova was a new study, considering the biological aspects in question, such as the immediate impacts suffered by the invertebrate community before and during the Feast of Our Lady of Lapa.

\section{ACKNOWLEDGMENTS}

To colleagues Érika Linzi S. Taylor, Maysa Fernanda V. R. de Souza, Marconi Souza Silva, for their help with field work. To the researchers, for the identification of taxonomic groups: Thaís Oliveira do Carmo (Psocoptera), Leopoldo F. O. Bernardi (Acari), Maysa Fernanda V. R. de Souza (Palpigradi) and Daniele C. Pompeu (Pseudoscorpiones). To researcher Paulo dos Santos Pompeu, for his assistance with statistical analyses. To Votorantim Metais and Carste Consultores Associados Ltda for the financial support given to this work. Rodrigo L. Ferreira thanks CNPQ for the fellowship, no. 301061/2011-4. Thais G. Pellegrini is really grateful to CAPES for the scholarship and to Graduate Program in Applied Ecology of the Universidade Federal de Lavras. We also thank FAPEMIG for the financial support, no. APQ-0185409. Finally we thank Dr. Tanja Pipan for the suggestions, and anonymous reviewers for their valuable comments, and Marcelo Dalpasquale and Ross Thomas for English editing and review.

\section{REFERENCES}

Auler A.S., Rubbioli E. \& Brandi R., 2001 - As grandes cavernas do Brasil. Grupo Bambui de Pesquisas Espeleológicas. Belo Horizonte, 228 p.

Barr T.C. \& Holsinger J.R., 1985 - Speciation in cave faunas. Annual Review of Ecology and Systematics, 16: 313-337. http://dx.doi.org/10.1146/annurev.es.16.110185.001525

Barr T.C. \& Kuehne R.A., 1971 - Ecological studies in Mammoth Cave ecosystems of Kentucky. II The ecosystem. Annales de Spéléologie, 26: 47-96.

Baker A. \& Genty D., 1998 - Environmental pressures on conserving cave speleothems: effects of changing cave tourism. Journal of Environmental Management, 53: 165-175. http://dx.doi.org/10.1006/jema.1998.0208

Bernardi L.F.O., Souza-Silva M. \& Ferreira R.L., 2010 - Considerações sobre os efeitos do turismo no ecossistema da Mina do Chico Rei (Ouro Preto, Minas Gerais): implicações para o manejo em sistemas naturais.Turismo e Paisagens Cársticas, 3(2): $67-77$.

Bocic N., Lukic A. \& Opacic V.T., 2006 - Management models and development of show caves as tourist destinations in Croatia. Acta Carsologica, 35(2): 13-21.

Calaforra J.M., Fernández-Cortés A., SánchezMartos F., Gisbert J. \& Pulido-Bosch A., 2003 - Environmental control for determining human impact and permanent visitor capacity in a potential show cave before tourist use. Environmental Conservation, 30(2): 160-167.

http://dx.doi.org/10.1017/S0376892903000146

Carste C. A., 2009 - Plano de Manejo Espeleológico de Lapa Nova, Vazante, Minas Gerais. Votorantim metais, $118 \mathrm{p}$.

Cigna A.A., 2005 - Show Caves. In: Culver D.C. \& White W.B. (Eds)., Encyclopedia of Caves, Elsevier Academic Press, San Diego: 495-500. 
Culver D.C. \& Pipan T., 2008 - The Biology of Caves and other Subterranean Habitats. Oxford University Press. $1^{\text {st }}$ edn. Oxford University Press, New York, 254 p.

Culver, D. C. \& Sket B., 2002 - Biological monitoring in caves. Acta Carsologica. 31(1): 55-64.

Eberhard S., 2001 - Cave fauna monitoring and management at Ida Bay, Tasmania. Records of the Western Australia Museum Supplement, 64: 97104.

Ferreira R.L., 2004 - A medida da complexidade ecológica e suas aplicações na conservação e manejo de ecossistemas subterrâneos.Dactoral thesis, Universidade Federal de Minas Gerais, Belo Horizonte.

Ferreira R.L., Bernardi L.F.O. \& Souza-Silva M., 2009 - Caracterização dos ecossistemas das Grutas Aroê Jari, Kiogo Brado e Lago Azul (Chapada dos Guimarães, MT): Subsideos para o turismo nestas cavidades. Revista de Biologia e Ciências da Terra, 9(1): 41-58.

Gunn J., Hardwick P. \& Wood P.J., 2000 - The invertebrate community of the Peak - Speedwell cave system, Derbyshire, England - pressures and considerations for conservation management.Aquatic Conservation: Marine and Freshwater Ecosystems, 10: 353-369. http://dx.doi.org/10.1002/1099-0755 (200009/10) 10:5<353::AID-AQC413>3.0.CO;2-S

Hamilton-Smith E., 2004 - Tourist Caves. In: Gunn, J. (Ed). - Encyclopedia of Caves and Karst Science. Taylor and Francis Group, New York, London: 1554-1561.

Lobo H.A.S., Veríssimo C.U.V., Figueiredo L.A.V. \& Rasteiro M.A., 2007 - Potencial Geoturístico da Paisagem Cárstica. Global Turismo, 3(2), 20 p.
Marra R.J.C., 2001 - Espeleo turismo: planejamento e manejo de cavernas. Brasília: WD Ambiental.

Oliveira Mello A., 1977 - Da visão da lapa ao minério: Vazante. Prefeitura Municipal de Vazante, 194 p.

Poulson T.L. \& White W.B., 1969 - The cave environment. Science, 165: 971-981. http://dx.doi.org/10.1126/science.165.3897.971

Pulido-Bosch A., Rosales W.M., Chicano M.L., Navarro C.M.R. \& Vallejos A., 1997 - Human impact in a tourist karstic cave (Aracena, Spain). Environmental Geology, 31(3/4): 142-149. http://dx.doi.org/10.1007/s002540050173

Romero A., 2009 - Cave Biology. Cambridge University Press, New York, 319 p. http:/ /dx.doi.org/10.1017/CBO9780511596841

Russel M.J. \& Maclean V.L., 2008 - Management issues in a Tasmanian tourist cave: Potential microclimatic impacts of cave modifications. Journal of Environmental Management, 87: 474-483. http://dx.doi.org/10.1016/j.jenvman.2007.01.012 Sessegolo G.C., Oliveira K., Pries D.C., Rocha L.F.S. \& Zakrzewski D.P., 2004a - Sintese do plano de manejo do Parque Natural Municipal das Grutas de Botuverá, estado de Santa Catarina. IV Congresso Brasileiro de Unidades de Conservação. Anais, volume I (Trabalhos técnicos), 446-453.

Sessegolo G.C., Pries D.C., Rocha L.F.S., Pinto-daRocha R. \& Zarkrzewski D.P., 2004b - Manejo da caverna do Maroaga, Presidente Figueiredo/ AM. IVCongresso Brasileiro de Unidades de Conservação. Anais, volume I (Trabalhos técnicos), 399-405.

Song L., Wei X. \& Liang F., 2000 - The influences of cave tourism on $\mathrm{CO}_{2}$ and temperature in Baiyun Cave, Hebei, China. International Journal of Speleology, 29 B (1/4): 77-87. 